\title{
Physiological Activity of Aconitum pseudolaeve var erectum Nakai and Its Effect on Perfume on an Electroencephalogram (EEG)
}

\author{
Jin Young Lee ${ }^{1}$, Yeonhee Choi $^{2}$, Saemi Lee ${ }^{2}$, Soo Yeon Lee ${ }^{1}$ and Hye Ji Jun ${ }^{1}$ \\ ${ }^{1}$ Department of Herbal Cosmetic Science, Hoseo University, Asan, Chungnam 336-795, Korea \\ ${ }^{2} J S$ Perfumery Co, Ltd, Fragrance R\&D center, Seongnam 462-120, Korea
}

Received July 3, 2012 /Revised August 30, 2012 /Accepted September 5, 2012

\begin{abstract}
This study analyzed the in vitro physiological activity of Aconitum pseudolaeve var erectum Nakai (AP) and its effect on perfume on an electroencephalogram (EEG). The results indicated that the absolute alpha power spectrum (AA) and the absolute theta power spectrum (AT) decreased significantly during more than before the inhalation of the AP perfume and its reconstruction perfume. Although there were a little different pattern in the induced part of the wave generated by the inhalation of the AP perfume and its reconstruction perfume, alpha- and theta- were shown equally. In addition, there was the same pattern in which the rate of increase reduced. The results suggest that the perfume of the $\mathrm{AP}$ and its reconstruction perfume have a stimulating effect on the brain. In terms of the physiological activity of $\mathrm{AP}$, the activity of $\mathrm{AP}$ ethanol extract was significantly higher than that of water extract in DPPH, collagenase, and nitric oxide, except for an astringent effect. The AP ethanol extract was about $80 \%$ at $500 \mathrm{ppm}$ in collagenase inhibition activity. In addition, the AP water and ethanol extracts were $50 \%$ at $100 \mathrm{ppm}$ in the NO inhibition activity. Based on these results, we conclude that this natural substance could be used in cosmetics and in the development of perfumes.
\end{abstract}

Key words : Aconitum pseudolaeve Nakai, electroencephalogram (EEG), physiological activity, perfume

\section{서 론}

뇌파는 두피에서 자발적으로 발생하는 전위로 뇌신경세포 의 활동에 수반되어 생성되는 전기적 변화를 머리 표면에 부 착한 전극에 의해 비침습적인 방법으로 측정하는 전기 신호이 다. 따라서 뇌파는 시시각각으로 변화하는 뇌 활동의 변동을 시간적, 공간적으로 파악할 수 있는 자료가 되고[27], 지필 평 가와는 달리 객관적으로 뇌 활동의 변화를 해석할 수 있는 방법으로 인정되고 있어[19], 뇌파의 파형을 분석하여 정량화 함으로서 피보험자가 어떤 자극을 받았을 때의 긴장도나 쾌적 한 정도를 우세하게 출현하는 뇌파를 위주로 해석하여 정서반 응의 차이를 평가할 수 있다. 정상인이 흥분하거나 특정한 과 제에 주의를 집중할 때에는 대뇌피질의 세포들이 상호 조화하 여 진동하지 않는 비동기화 현상에 의해 $13 \mathrm{~Hz}$ 에서 $30 \mathrm{~Hz}$ 사이 주파수의 $\beta$ 파가 활성화 된다[17]. 그러나 안정을 취하고 있을 때에는 대뇌피질의 세포들이 거의 동시에 활동하는 동기화 현 상에 의해 두정부와 후두부에서 $a$ 파가 우세하게 나타난다[2]

좋은 향기는 사람의 기분을 좋게 해주며 이미지 개선에 있 어 중요한 요소로 손꼽히고 있다. 특히 후각을 고려하여 천연 향을 이용한 제품 개발에 관심을 기울이고 있으나, 천연향은 특유의 향 때문에 선호도가 낮은 경향을 보이고 있다[28]. 최근

*Corresponding author

Tel : +82-41-540-9552, Fax : +82-41-540-9538

E-mail : jylee@hoseo.edu
향이 긴장과 완화 등에 있어서 중요한 역할을 한다는 사실이 과학적으로 증명되고 있으며, 향을 통한 자극이 후각세포를 통해 뇌에 전달되는 속도는 매우 빠르다는 사실이 밝혀 졌다 [3]. 이런 향의 작용은 신체의 활력과 면역력을 증진시켜 건강 유지에 도움을 주며, 인간의 정서적 안정과 감성의 변화에 영 향을 주고 있다. 이러한 천연 향을 탐색하는 중 우리나라 산지 의 그늘에서 자생하는 미나리아재비과의 진범(Aconitum pseudolaeve var erectum Nakai)을 탐색하게 되었다. 진범은 Aconitum 속에 속하는 다년초로서 그 뿌리는 한약 또는 민간 에서 진통, 진경, 이뇨, 거풍습약으로 사용되어 왔고, 진범의 성분에는 지하부에서 lycoctonine type의 $\mathrm{C}_{19}$-diterpene 계 alkaloid인 avadharidine, lycoctonine과 septentriodine 등의 alkaloid와 aromatic amide인 methyl-N-(3-carbamoylpropionyl) anthranilate와 methyl-N-(2-acetaminobenzoyl) anthranilate 등이 풍부하다는 보고가 있다[11,18]. 이에 진범의 in-vitro 생리활성을 검증하고, 진범정유(원액) 및 진범 재조합 향료를 제조하여 신경생리학적으로 뇌파에 미치는 영향을 비 교 분석하여, 화장품 및 향료의 기능성 천연 소재로 사용하고 자 한다.

\section{재료 및 방법}

재료 및 시료의 추출

본 연구의 공시료는 경북 고령에서 재배된 진범을 한국 식 
물도감을 참고하여 동정 후 사용하였다. 진범의 생리활성 검 증을 위한 추출은 열수 및 에탄올 추출을 하였으며, 열수 추출 물의 경우 시료 $100 \mathrm{~g}$ 에 증류수 10 배 양을 가하여 $85^{\circ} \mathrm{C}$ 에서 3 시간 환류냉각 추출하여 상등액과 침전물을 분리하여 3 회 반복 추출하였으며, 에탄올 추출물은 $70 \%$ 에탄올을 시료 중량 의 10 배 양을 가하여 실온에서 24시간 침지하여 상등액과 침 전물을 분리하여 동일한 방법으로 3 회 반복 추출하였다. 또한 진범(생제)의 원액을 정유하기 위하여 진범 $2 \mathrm{~kg}$ 을 열수 추출 하여 물 부분을 diethyl ether 분액 후 농축하여 본 실험의 시료 로 사용하였다.

\section{뇌파 측정 환경 및 재료}

남녀 각각 5 명씩 총 10 명의 피험자를 대상으로 뇌파를 측정 하였으며, 측정 장소는 일정한 온도 $\left(23^{\circ} \mathrm{C}\right)$ 와 습도 $(50 \%)$ 를 유지 한 $32.4 \mathrm{~m}^{2}$ (9.8평) 크기의 실험실에서 최대한 잡음이 혼입되지 않은 안정적인 상태에서 뇌파를 측정하였다.

\section{뇌파 측정 재료 및 기기}

진범 정유(원액) 및 진범 재조합 향료를 향 흡입에 사용하였 으며, 뇌파 측정 시 사용한 기기는 QEEG-8 System (LXE 3208, LAXTHA Inc., Daejeon, Korea)를 사용하였으며, 피험자의 뇌 파 신호 측정은 Telescan program (LAXTHA Inc., Daejeon, Korea)을 이용하여 분석하였다.

\section{뇌파 측정 및 분석 방법}

\section{뇌파 전극 부착}

10-20 국제 전극 배치법[15]을 이용하여 8개의 접지전극에 뇌파전용 무해 접착 풀을 묻혀 피험자의 전전두엽 $(\mathrm{Fp} 1, \mathrm{Fp} 2)$, 전두엽(F3, F4), 측두엽(T3, T4), 두정엽(P3, P4) 부분에 부착하 고 오른쪽과 왼쪽 귓 볼 뒷부분에도 각각 하나씩의 전극을 부착하였다(Fig. 1).

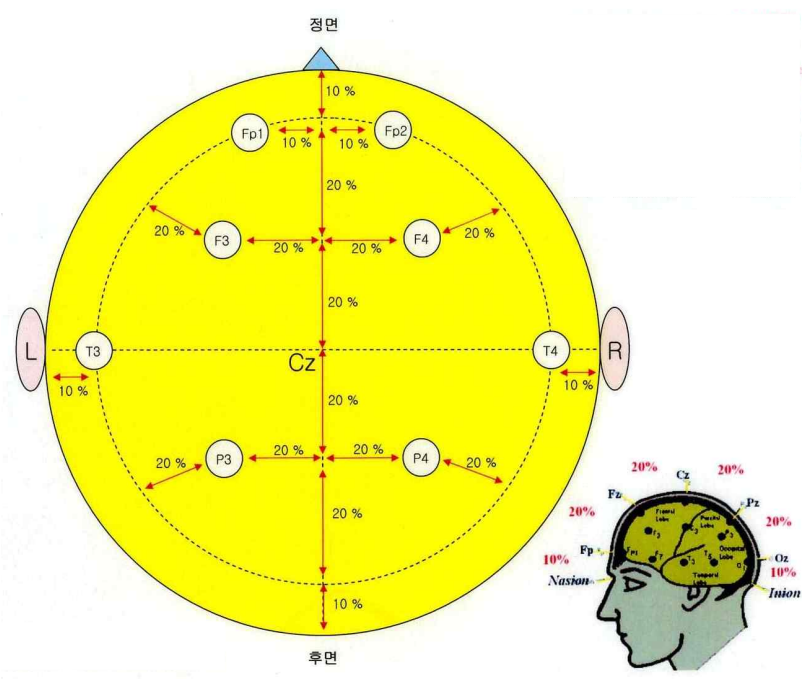

Fig. 1. International 10-20 system of electrode placement.

\section{향 흡입}

진범 정유는 vial에 담겨진 상태로, 진범 재조합 향료는 시 향지 $(13 \mathrm{~cm})$ 로 찍어 피험자의 코로부터 약 $3 \mathrm{~cm}$ 거리를 유지 하고 피험자가 눈을 감은 상태에서 향 흡입 전(무자극)과 흡입 상태(향자극)로 각각 1 분씩을 측정하였다.

\section{데이터 분석}

뇌파측정을 한 10 명의 피험자 중 2 명으로부터 잡파가 발견 되어 이를 제외한 8 명의 뇌파신호로부터 1 분 측정 중 30 초 측정된 뇌파신호만을 추출하여 일괄처리 프로그램(Batch processing)으로 데이터 처리를 하였고, SPSS 18.0 version의 통계 분석 프로그램을 사용하여 대응표본 T검정을 하였다.

\section{생리활성 측정 시약}

항산화 효과 측정에 사용된 시약인 1,1-diphenyl-1-picrylhydrazyl (DPPH), pyrogallol, xanthine oxidase, 2.6-dihydroxypurin과 미백효과와 수렴효과 측정에 사용된 시약인 4-phenylazobenzyloxycarbonyl-Pro-Leu-Gly-Pro-D-Arg, collagenase, hemoglobin 등은 Sigma Chemical Co. (St. Louis, $\mathrm{MO}, \mathrm{USA}$ )에서 구입하여 사용하였다. 또한 세포 생존율 측정 에 사용된 macrophage 세포인 Raw 264.7은 Korean Cell Line Bank (KCLB)에서 구입하여 사용하였으며, 세포 생존율 측정 시약인 DMEM (Dulbecco's Modified Eagle Medium), fetal bovine serum (FBS), penicillin/streptomycin, trypsin 250, 3-[4,5-dimethylthiazol-2-yl]-2,5-diphenyl-tetrazoliumbromide (MTT)와 항염증 측정시약인 griess reagent는 Sigma Chemical Co. (St. Louis, MO, USA)에서 구입하여 사용하였다.

\section{$\mathrm{DPPH}$ 전자공여능 측정}

전자공여능(EDA: electron donating ability)은 Blois의 방법 [4]을 변형하여 측정하였다. 각 시료용액 $2 \mathrm{ml}$ 에 $0.2 \mathrm{mM}$ 의 $\mathrm{DPPH} 1 \mathrm{ml}$ 을 넣고 교반한 후 30분간 방치한 다음 $517 \mathrm{~nm}$ 에서 흡광도를 측정하였다. 전자공여능은 시료용액의 첨가군과 무 첨가군의 흡광도 감소율로 나타내었다.

$$
\text { 전자공여능 }(\%)=\left(1-\frac{\text { 시료첨가군의 흡광도 }}{\text { 무첨가군의 흡광도 }}\right) \times 100
$$

\section{Superoxide dismutase (SOD) 유사활성 측정}

SOD 유사활성은 Marklund 등의 방법[23]에 따라 측정하였 다. 각 시료용액 $0.2 \mathrm{ml}$ 에 Tris $\mathrm{HCl}$ 의 완충용액 $(50 \mathrm{mM}$ Tris + $10 \mathrm{mM}$ EDTA, pH 8.5) $2.6 \mathrm{ml}$ 와 $7.2 \mathrm{mM}$ 의 pyrogallol 0.2 $\mathrm{ml}$ 를 가하여 $25^{\circ} \mathrm{C}$ 에서 10 분간 반응시킨 후 $1.0 \mathrm{~N} \mathrm{HCl} 0.1 \mathrm{ml}$ 를 가하여 반응을 정지시키고 반응액 중 산화된 pyrogallol의 양을 $420 \mathrm{~nm}$ 에서 측정하였다. SOD 유사활성은 시료용액의 첨가군과 무첨가군의 흡광도 감소율로 나타내었다.

$$
\mathrm{SOD} \text { 유사활성능 }(\%)=\left(1-\frac{\text { 시료첨가군의 흡광도 }}{\text { 무첨가군의 흡광도 }}\right) \times 100
$$




\section{Collagenase 저해활성 측정}

Collagenase 저해활성 측정은 Wunnsch 등의 방법[31]에 따 라 측정하였다. 즉 반응구는 $0.1 \mathrm{M}$ tris-HCl buffer $(\mathrm{pH}$ 7.5)에 $4 \mathrm{mM} \mathrm{CaCl}$ 를 첨가하여, 4-phenylazobenzyl-oxycarbonylPro-Leu-Gly-Pro-D-Arg $(0.3 \mathrm{mg} / \mathrm{ml})$ 을 녹인 기질액 $0.25 \mathrm{ml}$ 및 시료용액 $0.1 \mathrm{ml}$ 의 혼합액에 collagenase $(0.2 \mathrm{mg} / \mathrm{ml}) 0.15$ $\mathrm{ml}$ 을 첨가하여 실온에서 20 분간 방치한 후 $6 \%$ citric acid 0.5 $\mathrm{ml}$ 을 넣어 반응을 정지 시킨 후, ethyl acetate $1.5 \mathrm{ml}$ 을 첨가하 여 $320 \mathrm{~nm}$ 에서 흡광도를 측정하였다. Collagenase 저해활성 은 시료용약의 첨가구와 무첨가구의 흡광도 감소율로 나타내 었다.

$$
\text { 저해율 }(\%)=\left(1-\frac{\text { 시료첨가군의 흡광도 }}{\text { 무첨가군의 흡광도 }}\right) \times 100
$$

\section{Astringent 활성 측정}

Astringent 활성 측정은 Lee 등의 방법[20]에 따라 측정하였 다. 피부 단백질과 유사한 혈액 단백질(hemoglobin)을 사용하 여, 원심분리 관 용기에 각각의 시료용액과 헤모글로빈 용액 을 $0.5 \mathrm{ml}$ 씩 $1: 1$ 로 넣어서 진탕 혼합한 다음 $1,500 \mathrm{rpm}$ 에서 3 분간 원심분리 후 $576 \mathrm{~nm}$ 에서 흡광도를 측정하였다. Astringent 활성 측정은 시료용액의 첨가 군과 무 첨가 군의 흡광도 감소율로 나타내었다.

$$
\text { Astringent 활성능 }(\%)=\left(1-\frac{\text { 시료첨가군의 흡광도 }}{\text { 무첨가군의 흡광도 }}\right) \times 100
$$

\section{MTT assay에 의한 세포 생존율 측정}

세포 생존율 측정은 Carmichael 등의 방법[5]에 따라 측정 하였다. 세포주 macrophage (Raw 264.7) cell을 96 well plate 에 $5 \times 10^{3}$ cells/well이 되게 $0.2 \mathrm{ml}$ 분주하여 $37^{\circ} \mathrm{C}, 5 \% \mathrm{CO}_{2}$ incubator에서 24시간 배양한 후, 무혈청배지 $0.18 \mathrm{ml}$ 에 시료 를 농도 별로 조제하여 $0.02 \mathrm{ml}$ 첨가한 후 대조군은 시료와 동량의 무혈청 배지를 첨가하여 동일한 조건으로 배양하였다. 여기에 $2.5 \mathrm{mg} / \mathrm{ml}$ 농도로 제조한 MTT 용액 $0.02 \mathrm{ml}$ 를 첨가하 여 3시간 배양한 후 배양액을 제거하고 각 well당 DMSO 0.1 $\mathrm{ml}$ 를 가하여 실온에서 30 분간 반응 시킨 뒤 ELISA reader (Tecan, Austria)로 $540 \mathrm{~nm}$ 에서 흡광도를 측정하였다. 세포 생존율 측정은 시료용액의 첨가군와 무첨가군의 흡광도 감소 율로 나타내었다.

$$
\text { 세포 생존율 }(\%)=\left(1-\frac{\text { 시료첨가군의 흡광도 }}{\text { 무첨가군의 흡광도 }}\right) \times 100
$$

\section{Nitric oxide 저해활성 측정}

Nitric oxide $(\mathrm{NO})$ 측정은 세포배양액에서 $\mathrm{NO}$ 의 양을 nitrite와 nitrate로서 측정하였다. 96 well plate에 $1 \times 10^{4}$ cells/well이 되게 $0.2 \mathrm{ml}$ 분주하여 $37^{\circ} \mathrm{C}, 5 \% \mathrm{CO}_{2}$ incubator에
서 24시간 배양한 후, PBS로 washing한 후에 무혈청 배지 0.18 $\mathrm{ml}$ 에 시료를 농도 별로 조제하여 $0.02 \mathrm{ml}$ 첨가한 후 대조군은 시료와 동량의 무혈청 배지를 첨가하여 동일한 조건으로 배양 하였다. NO 생성량은 supernatant를 모아 griess regent로 반 응시킨 후에 $540 \mathrm{~nm}$ 에서 흡광도로 측정하였다. Nitric oxide 측정은 시료용액의 첨가군와 무첨가군의 흡광도 감소율로 나 타내었다.

$$
\text { Nitric oxide }(\%)=\left(1-\frac{\text { 시료첨가군의 흡광도 }}{\text { 무첨가군의 흡광도 }}\right) \times 100
$$

\section{결과 및 고찰}

진범 향과 진범 재조합 향이 뇌파 지표 absolute alpha power spectrum (AA)에 미치는 영향

Absolute alpha power spectrum (AA) 지표는 뇌파 스펙트 럼에서 8 13 Hz의 alpha파 영역의 절대파워 스펙트럼 값을 의미한다. Alpha파는 긴장을 풀고 깨어있는 상태에서 눈을 감고 있을 때 나타나는 파형으로 정신적 안정 상태이거나 기 분이 편안하고 느긋할 때, 조용한 명상음악을 듣거나 명상 중 일 때 또는 외부 자극에 습관화되었을 때 나타난다[14]. 진범 향 흡입 전과 흡입 중일 때의 뇌파 측정 결과를 Table 1 에 나타 내었다. 전극부착부위(채널) 중 좌·우 전두엽(F3, F4), 좌측 측 두엽(T3), 좌측 두정엽(P3)에서 alpha파의 뇌파분석 지표인 $\mathrm{AA}$ 평균값이 통계적으로 유의미하게 감소한 것을 확인할 수 있었다 $(p<0.05)$. 즉 alpha파의 감소가 나타난 전두엽은 대뇌피 질의 일반적인 각성 상태 및 인간의 정신작용이 가장 복잡한 목표 지향적 행동과 주의(attention)를 통제하는 역할을 하고 [8], 측두엽은 고도의 인지, 기억, 감정 및 정신적 기능과 관련 이 깊으며[21], 두정엽은 계산과정, 공간적 정신 활동 및 추론 활동과 직접 관련되는 것으로 알려져 있다[1,24]. 위의 내용을 볼 때 좌·우 전두엽 $(\mathrm{F} 3, \mathrm{~F} 4)$, 좌측 측두엽 $(\mathrm{T} 3)$, 좌측 두정엽 $(\mathrm{P3})$ 에서 alpha파가 감소한 결과는 진범 향 흡입 시 뇌에 각성이 일어났음을 의미한다.

또한 진범 재조합 향의 경우 Table 2에서 보는 것과 향 흡입 전과 흡입 시의 전극부착부위(채널) 중 좌측 측두엽(T3) 및 좌 측 두정엽(P3) 채널에서 alpha파의 뇌파분석 지표인 $\mathrm{AA}$ 평균 값이 통계적으로 유의미하게 감소한 것을 확인할 수 있었다 $(p<0.05)$. 이는 진범 재조합 향 흡입 시 정신적 기능과 관련된 측두엽 부위와 공간적 정신활동 및 추론활동과 관련된 두정엽 부위로부터 유발된 alpha파가 감소함으로서 뇌가 각성되었음 을 의미한다.

Brain map으로 본 진범 향 흡입 전과 흡입 시 alpha파 변화

진범 향 흡입 전과 흡입 시 alpha파 변화를 brain map을 통하여 확인한 결과 Fig. 2, 3과 같이 나타났다. 좌측에 보이는 
Table 1. Change of alpha-wave from brain before and during Aconitum pseudolaeve var erectum Nakai perfume inhalation

\begin{tabular}{|c|c|c|c|c|c|c|}
\hline \multicolumn{7}{|c|}{ Absolute alpha power spectrum (AA) } \\
\hline Sites & Inhalation & $\mathrm{N}$ & Mean & SD & t-test & $\mathrm{p}$ \\
\hline \multirow{2}{*}{ Fp1 } & Before & 8 & 17.716 & 8.240 & \multirow{2}{*}{-0.396} & \multirow{2}{*}{0.704} \\
\hline & During & 8 & 17.203 & 8.298 & & \\
\hline \multirow{2}{*}{ Fp2 } & Before & 8 & 22.369 & 15.568 & \multirow{2}{*}{-2.144} & \multirow{2}{*}{0.069} \\
\hline & During & 8 & 18.128 & 12.204 & & \\
\hline \multirow{2}{*}{ F3 } & Before & 8 & 32.743 & 19.403 & \multirow{2}{*}{$-2.877^{*}$} & \multirow{2}{*}{0.024} \\
\hline & During & 8 & 24.563 & 14.496 & & \\
\hline \multirow{2}{*}{ F4 } & Before & 8 & 29.545 & 17.266 & \multirow{2}{*}{$-2.831^{*}$} & \multirow{2}{*}{0.025} \\
\hline & During & 8 & 23.108 & 12.849 & & \\
\hline \multirow{2}{*}{ T3 } & Before & 8 & 22.553 & 11.253 & \multirow{2}{*}{$-4.496^{*}$} & \multirow{2}{*}{0.003} \\
\hline & During & 8 & 15.912 & 8.903 & & \\
\hline \multirow{2}{*}{$\mathrm{T} 4$} & Before & 8 & 13.778 & 6.967 & \multirow{2}{*}{-1.762} & \multirow{2}{*}{0.121} \\
\hline & During & 8 & 11.569 & 5.434 & & \\
\hline \multirow{2}{*}{ P3 } & Before & 8 & 52.696 & 36.056 & \multirow{2}{*}{$-2.372^{*}$} & \multirow{2}{*}{0.049} \\
\hline & During & 8 & 38.646 & 26.673 & & \\
\hline \multirow{2}{*}{ P4 } & Before & 8 & 51.125 & 42.558 & \multirow{2}{*}{-1.714} & \multirow{2}{*}{0.130} \\
\hline & During & 8 & 41.273 & 32.014 & & \\
\hline
\end{tabular}

Fp1: Left prefrontal, Fp2: Right prefrontal, F3: Left frontal, F4: Right frontal, T3: Left temporal, T4: Right temporal, P3: Left parietal, P4: Right parietal.

Table 2. Change of alpha-wave from brain before and during Aconitum pseudolaeve var erectum Nakai reconstruction perfume inhalation

\begin{tabular}{|c|c|c|c|c|c|c|}
\hline \multicolumn{7}{|c|}{ Absolute alpha power spectrum (AA) } \\
\hline Sites & Inhalation & $\mathrm{N}$ & Mean & SD & t-test & $\mathrm{p}$ \\
\hline \multirow{2}{*}{ Fp1 } & Before & 8 & 17.716 & 8.240 & \multirow{2}{*}{-0.115} & \multirow{2}{*}{0.911} \\
\hline & During & 8 & 17.498 & 7.852 & & \\
\hline \multirow{2}{*}{ Fp2 } & Before & 8 & 22.369 & 15.568 & \multirow{2}{*}{0.633} & \multirow{2}{*}{0.547} \\
\hline & During & 8 & 23.542 & 16.085 & & \\
\hline \multirow{2}{*}{ F3 } & Before & 8 & 32.743 & 19.403 & \multirow{2}{*}{-0.441} & \multirow{2}{*}{0.672} \\
\hline & During & 8 & 30.990 & 16.312 & & \\
\hline \multirow{2}{*}{ F4 } & Before & 8 & 29.545 & 17.266 & \multirow{2}{*}{0.282} & \multirow{2}{*}{0.786} \\
\hline & During & 8 & 30.509 & 15.450 & & \\
\hline \multirow{2}{*}{ T3 } & Before & 8 & 22.553 & 11.253 & \multirow{2}{*}{$-3.056^{*}$} & \multirow{2}{*}{0.018} \\
\hline & During & 8 & 17.105 & 8.207 & & \\
\hline \multirow{2}{*}{$\mathrm{T} 4$} & Before & 8 & 13.778 & 6.967 & \multirow{2}{*}{-0.738} & \multirow{2}{*}{0.484} \\
\hline & During & 8 & 12.680 & 5.731 & & \\
\hline \multirow{2}{*}{ P3 } & Before & 8 & 52.696 & 36.056 & \multirow{2}{*}{$-2.877^{*}$} & \multirow{2}{*}{0.024} \\
\hline & During & 8 & 36.088 & 21.648 & & \\
\hline \multirow{2}{*}{ P4 } & Before & 8 & 51.125 & 42.558 & \multirow{2}{*}{-2.343} & \multirow{2}{*}{0.052} \\
\hline & During & 8 & 39.088 & 30.840 & & \\
\hline
\end{tabular}

Fp1: Left prefrontal, Fp2: Right prefrontal, F3: Left frontal, F4: Right frontal, T3: Left temporal, T4: Right temporal, P3: Left parietal, P4: Right parietal.

value 7 색깔 막대기는 측정된 뇌파신호의 평균 데이터를 나타 낸 것으로, 각각의 뇌파지표 $(\mathrm{AA}, \mathrm{AT})$ 마다 각각 다른 값을 나 타낸다. Fp1, Fp2, F3, F4, T3, T4, P3, P4 위치에서 측정된 뇌파 신호 중 평균값이 높을수록 위쪽에 있는 색깔을 나타내고, 평 균값이 낮을수록 아래쪽에 있는 색깔을 나타낸다.

진범 향 흡입 전 좌우전두엽(F3, F4) 채널은 연한 하늘색을 나타내었고, 향 흡입 시 진한 파랑색을 나타내어 alpha파가 감소하였음을 확인할 수 있었으며, 좌측 측두엽(T3) 채널의
파랑색이 보라색으로, 좌측 두정엽(P3) 채널의 짙은 연두색이 연한 연두색으로 변하여 alpha파가 감소하였음을 확인할 수 있었다(Fig. 2).

또한 진범 재조합 향의 경우 흡입 전 좌측 측두엽(T3) 채널 의 파란색이 향 흡입 시 보라색으로 변하였으며, 좌측 두정엽 (P3) 채널의 짙은 연두색은 연한 청초록으로 변하여 alpha파 가 감소하였음을 확인할 수 있었다(Fig. 3). 


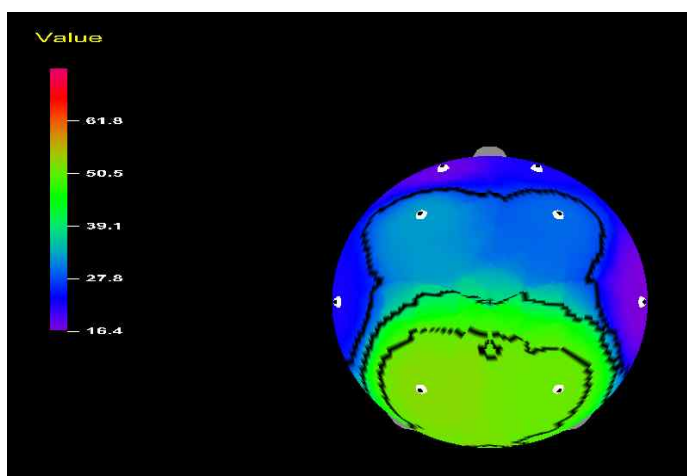

Before perfume inhalation

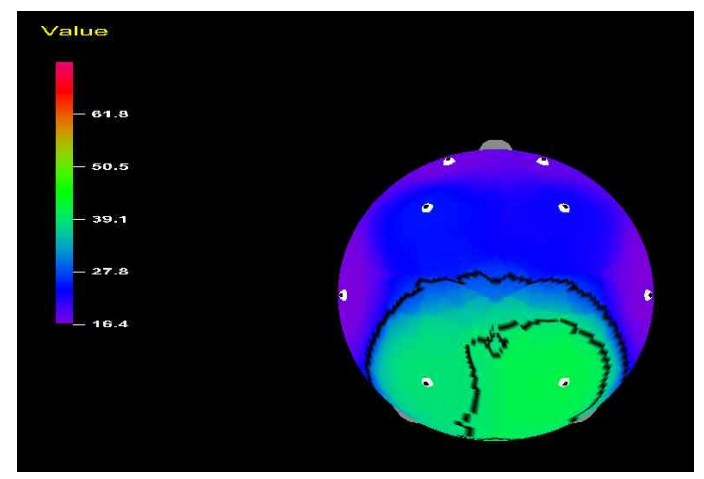

During perfume inhalation

Fig. 2. Change of alpha-wave from before and during Aconitum pseudolaeve var erectum Nakai perfume inhalation by the brain map.

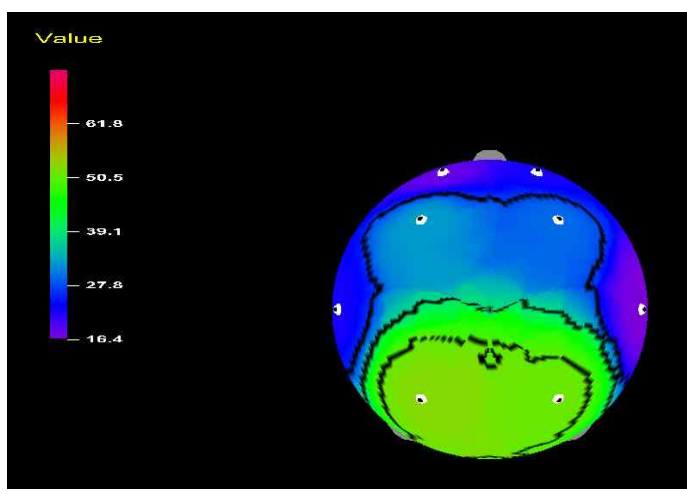

Before perfume inhalation

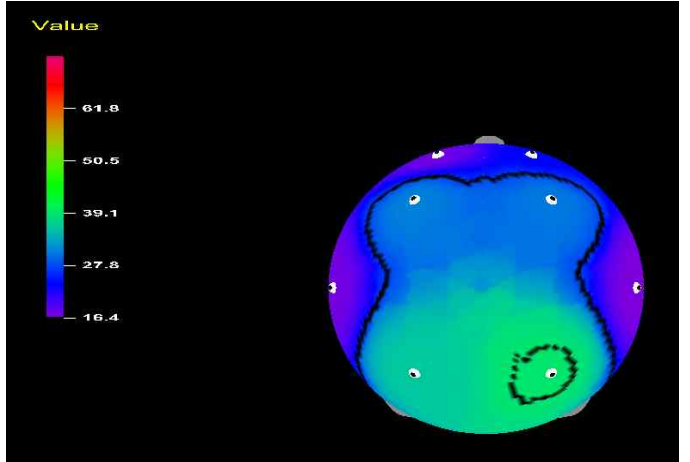

During perfume inhalation

Fig. 3. Change of alpha-wave from before and during Aconitum pseudolaeve var erectum Nakai reconstruction perfume inhalation by the brain map.

진범 향과 진범 재조합 향이 뇌파 지표 absolute theta power spectrum (AT)에 미치는 영향

Absolute theta power spectrum (AT) 지표는 뇌파 스펙트 럼에서 $4 \sim 8 \mathrm{~Hz}$ 의 theta파 영역의 절대파워 스펙트럼 값을 의 미한다. 깊이 내면화되고 조용한 상태의 육체, 감정 및 사고활 동과 관련된다[16]. 깊은 수면 상태가 아닌 졸릴 때 주로 나타 나며, 마음의 상처가 있거나 예술적인 노력을 기울일 때, 그리 고 즐겁고 기쁜 업무나 놀이 시에 크게 나타난다[30]. 진범 향 흡입 전과 흡입 중일 때의 뇌파 측정 결과를 Table 3에 나타내 었다. 전극부착부위(채널) 중 우측 두정엽( $\mathrm{P} 4)$ 채널에서 theta 파의 뇌파분석 지표인 $\mathrm{AT}$ 평균값이 통계적으로 유의미하게 감소한 것을 확인할 수 있었다( $p<0.05)$. 이는 진범 향 흡입 시 졸리고 몽롱한 상태가 완화됨으로서 뇌가 각성되었음을 의미 한다.

또한 진범 재조합 향의 경우 Table 4 에서 보는 것과 같이 흡입 전과 흡입 시 전극부착부위(채널) 중 좌측 전두엽(F3)과 우측 측두엽(T4) 채널에서 theta파의 뇌파분석 지표인 AT 평 균값이 통계적으로 유의미하게 감소한 것으로 나타났다 $(p<0.05)$. 새로운 것에 대한 호기심을 가지게 되면 좌·우뇌의 전두엽 부위에서는 집중력과 창의성에 큰 영향을 주는 신경 전달 물질인 도파민(dopamine)이 왕성하게 분비되고 이에 따라 두뇌는 최적의 각성상태를 유지하고 적절한 주파수를 갖는 뇌파가 나오게 된다[10,12]. 이는 진범 재조합 향 흡입 시 위 기술한 바와 같은 전두엽 및 정신활동과 관련된 측두 엽 부위에서 theta파가 감소함으로서 뇌에 각성을 일으켰음 을 의미한다.

Brain map으로 본 진범 향 흡입 전과 흡입 시 theta파 변화 진범 향 흡입 전과 흡입 시 theta파 변화를 brain map을 통하여 확인한 결과 Fig. 4,5 와 같이 나타났다. 향 흡입 전 우측 두정엽(P4) 채널의 연한 청초록이 향 흡입 시 연한 파란 색으로 변하였으며, 이는 theta파가 감소하였음을 확인할 수 있었다.

또한 진범 재조합 향의 경우 향 흡입 전 좌측 전두엽 $(\mathrm{F} 3)$ 채널의 연한 청초록이 향 흡입 시 연한 하늘색으로 변하였고, 우측 측두엽(T4) 채널의 보라색이 진 보라색으로 변하였는데, 
Table 3. Change of theta- wave from brain before and during Aconitum pseudolaeve var erectum Nakai perfume inhalation

\begin{tabular}{|c|c|c|c|c|c|c|}
\hline \multicolumn{7}{|c|}{ Absolute theta power spectrum (AT) } \\
\hline Sites & Inhalation & $\mathrm{N}$ & Mean & SD & t-test & $\mathrm{p}$ \\
\hline \multirow{2}{*}{ Fp1 } & Before & 8 & 13.712 & 9.803 & \multirow{2}{*}{-1.007} & \multirow{2}{*}{0.348} \\
\hline & During & 8 & 10.595 & 7.742 & & \\
\hline \multirow{2}{*}{ Fp2 } & Before & 8 & 10.668 & 8.930 & \multirow{2}{*}{0.935} & \multirow{2}{*}{0.381} \\
\hline & During & 8 & 12.337 & 13.151 & & \\
\hline \multirow{2}{*}{ F3 } & Before & 8 & 15.388 & 6.101 & \multirow{2}{*}{-1.767} & \multirow{2}{*}{0.121} \\
\hline & During & 8 & 13.410 & 5.106 & & \\
\hline \multirow{2}{*}{ F4 } & Before & 8 & 13.596 & 6.187 & \multirow{2}{*}{-2.349} & \multirow{2}{*}{0.051} \\
\hline & During & 8 & 11.965 & 6.146 & & \\
\hline \multirow{2}{*}{ T3 } & Before & 8 & 11.795 & 5.503 & \multirow{2}{*}{-1.195} & \multirow{2}{*}{0.271} \\
\hline & During & 8 & 10.769 & 4.415 & & \\
\hline \multirow{2}{*}{$\mathrm{T} 4$} & Before & 8 & 6.727 & 2.663 & \multirow{2}{*}{-2.208} & \multirow{2}{*}{0.063} \\
\hline & During & 8 & 5.667 & 3.123 & & \\
\hline \multirow{2}{*}{ P3 } & Before & 8 & 15.022 & 6.974 & \multirow{2}{*}{-2.046} & \multirow{2}{*}{0.080} \\
\hline & During & 8 & 12.365 & 4.677 & & \\
\hline \multirow{2}{*}{ P4 } & Before & 8 & 13.535 & 6.908 & \multirow{2}{*}{$-3.044^{*}$} & \multirow{2}{*}{0.019} \\
\hline & During & 8 & 10.933 & 5.881 & & \\
\hline
\end{tabular}

Fp1: Left prefrontal, Fp2: Right prefrontal, F3: Left frontal, F4: Right frontal, T3: Left temporal, T4: Right temporal, P3: Left parietal, P4: Right parietal.

Table 4. Change of theta- wave from brain before and during Aconitum pseuddaeve var erectum Nakai reconstruction perfume inhalation

\begin{tabular}{|c|c|c|c|c|c|c|}
\hline \multicolumn{7}{|c|}{ Absolute theta power spectrum (AT) } \\
\hline Sites & Inhalation & $\mathrm{N}$ & Mean & $\mathrm{SD}$ & t-test & p \\
\hline \multirow{2}{*}{ Fp1 } & Before & 8 & 13.712 & 9.803 & \multirow{2}{*}{-1.484} & \multirow{2}{*}{0.181} \\
\hline & During & 8 & 10.559 & 6.155 & & \\
\hline \multirow{2}{*}{ Fp2 } & Before & 8 & 10.668 & 8.930 & \multirow{2}{*}{-0.210} & \multirow{2}{*}{0.840} \\
\hline & During & 8 & 10.515 & 8.531 & & \\
\hline \multirow{2}{*}{ F3 } & Before & 8 & 15.388 & 6.101 & \multirow{2}{*}{$-3.162^{*}$} & \multirow{2}{*}{0.016} \\
\hline & During & 8 & 12.899 & 5.008 & & \\
\hline \multirow{2}{*}{ F4 } & Before & 8 & 13.596 & 6.187 & \multirow{2}{*}{-1.960} & \multirow{2}{*}{0.091} \\
\hline & During & 8 & 11.731 & 6.805 & & \\
\hline \multirow{2}{*}{ T3 } & Before & 8 & 11.795 & 5.503 & \multirow{2}{*}{-1.164} & \multirow{2}{*}{0.282} \\
\hline & During & 8 & 10.602 & 3.761 & & \\
\hline \multirow{2}{*}{$\mathrm{T} 4$} & Before & 8 & 6.727 & 2.663 & \multirow{2}{*}{$-3.140^{*}$} & \multirow{2}{*}{0.016} \\
\hline & During & 8 & 5.632 & 2.522 & & \\
\hline \multirow{2}{*}{ P3 } & Before & 8 & 15.022 & 6.974 & \multirow{2}{*}{-0.964} & \multirow{2}{*}{0.367} \\
\hline & During & 8 & 13.628 & 5.128 & & \\
\hline \multirow{2}{*}{ P4 } & Before & 8 & 13.535 & 6.908 & \multirow{2}{*}{-2.018} & \multirow{2}{*}{0.083} \\
\hline & During & 8 & 11.499 & 4.991 & & \\
\hline
\end{tabular}

Fp1: Left prefrontal, Fp2: Right prefrontal, F3: Left frontal, F4: Right frontal, T3: Left temporal, T4: Right temporal, P3: Left parietal, P4: Right parietal.

이는 theta파가 감소하였음을 나타낸다.

\section{$\mathrm{DPPH}$ 전자공여능 측정}

전자공여능 측정에 사용되는 $\mathrm{DPPH}$ 은 안정한 자유라디칼 로서 비공유전자로 인해 $517 \mathrm{~nm}$ 에서 최대 흡수치를 나타낸다. 전자 또는 수소를 받으면 흡광도가 감소하여 천연물에서 라디 칼을 환원시키거나 상쇄시키는 능력이 크면 항산화 활성 및 활성산소를 비롯한 다른 라디칼에 대한 소거활성을 기대할
수 있다. 또한 인체 내에서 활성 라디칼에 의한 노화를 억제하 는 척도로도 이용할 수 있다[29]. 진범의 열수 및 에탄올 추출 물의 항산화 효과를 확인한 결과 Fig. 6과 같이 나타내었다. 진범의 열수 추출물은 $500 \mathrm{ppm}$ 에서 $50 \%$ 이상의 효과를 나타 내었으며, 에탄올 추출물은 $65 \%$ 이상의 효과를 나타내었다. 이는 Hong 등[7]의 연구에서 흰씀바귀 메탄올 추출물이 500 $\mathrm{ppm}$ 에서 $41.7 \%$ 의 효과를 나타낸 것과 비교해 볼 때 진범의 열수 및 에탄올 추출물이 비교적 높은 항산화력을 가지고 있 


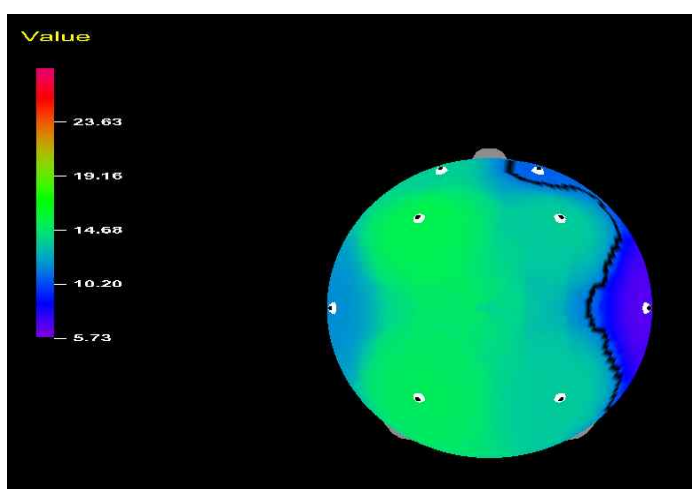

Before perfume inhalation

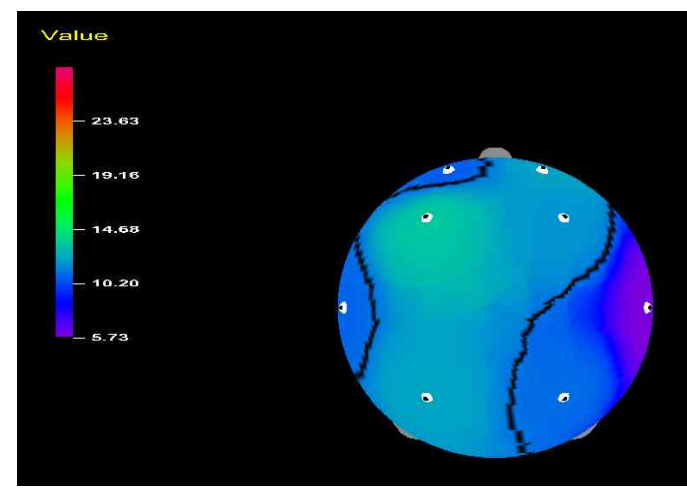

During perfume inhalation

Fig. 4. Change of theta-wave from before and during Aconitum pseudolaeve var erectum Nakai perfume inhalation by the brain map.

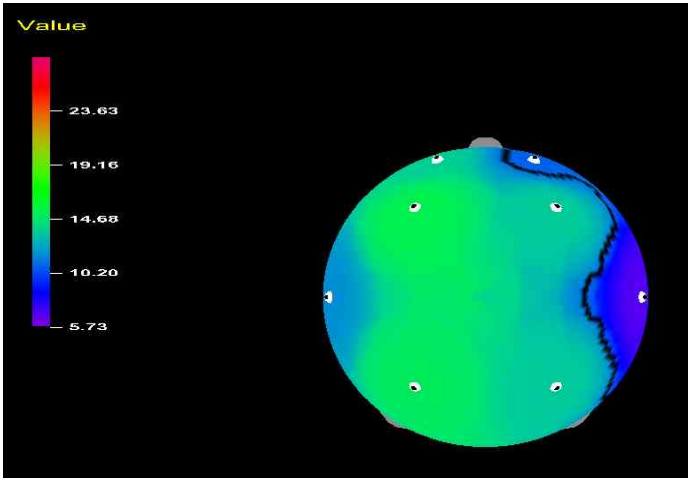

Before perfume inhalation

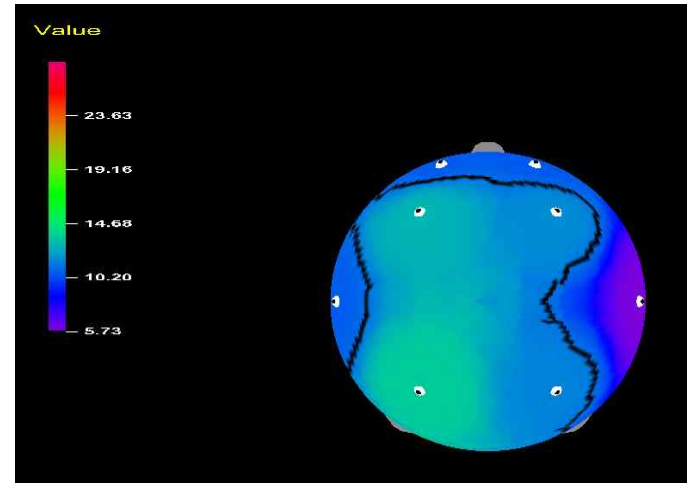

During perfume inhalation

Fig. 5. Change of theta- wave from before and during Aconitum pseudolaeve var erectum Nakai reconstruction perfume inhalation by the brain map.

는 것으로 확인되었다.

\section{Collagenase 저해활성 측정}

피부의 결합조직에는 collagen, elastin, fibronectin, integrin, fibrillin 등의 세포 외 기질 단백질이 존재하는데, 그 중 collagen이 진피층의 $90 \%$ 을 차지하고 있다. 이러한 collagen은 섬유아 세포에 의해 합성되며 피부의 기계적 견고 성, 결합조직의 저항력과 조직의 결합력, 세포접착의 지탱, 세 포분할과 분화의 유도, 피부의 탄력성을 갖게 하고 트립신과 같은 단백질 분해효소의 작용을 받지 않으나, collagenase에 의해 분해되어 피부의 주름생성을 촉진시킨다[6,29]. 이러한 collagenase 저해활성을 측정한 결과 Fig. 7과 같이 나타내었 다. 진범의 열수 추출물은 $1,000 \mathrm{ppm}$ 에서 $37.4 \%$ 의 저해율을 나타내었고, 에탄올 추출물은 이보다 낮은 농도인 $500 \mathrm{ppm}$ 에 서 $64.1 \%$ 의 저해율을 나타내어 열수 추출물에서 보다 에탄올 추출물에서의 collagense 저해활성이 높은 것으로 확인되었 다. 이는 Lee 등[22]의 연구에서 유백피 추출물 $1,000 \mathrm{ppm}$ 에서 $27.6 \%$ 의 저해활성을 나타낸 결과와 비교하여 진범의 에탄올

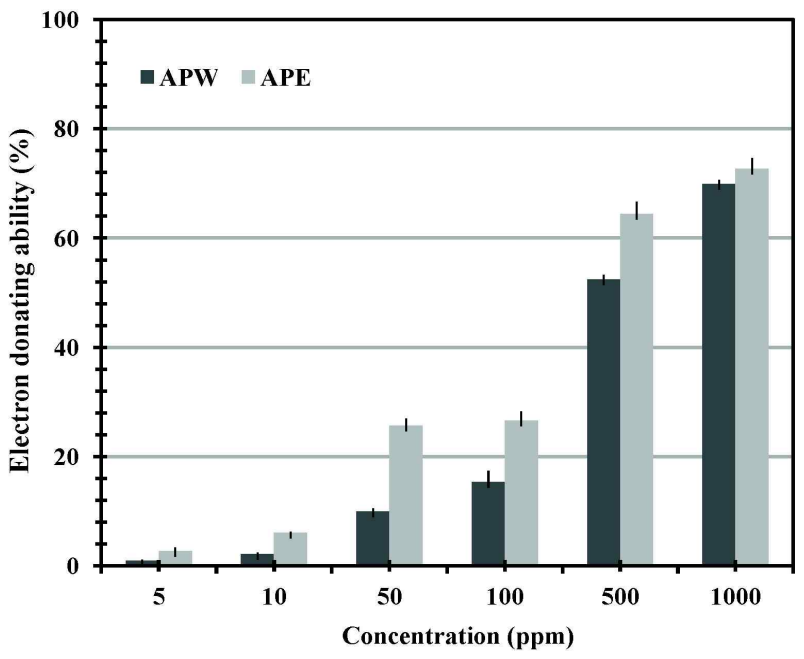

Fig. 6. Electron donating ability of Aconitum pseudolaeve var erectum Nakai. $\square$ APW: Aconitum pseudolaeve var erectum Nakai extracted with water. $\square$ APE: Aconitum pseudolaeve var erectum Nakai extracted with ethanol. Result are means \pm S.D. of triplicate data. 


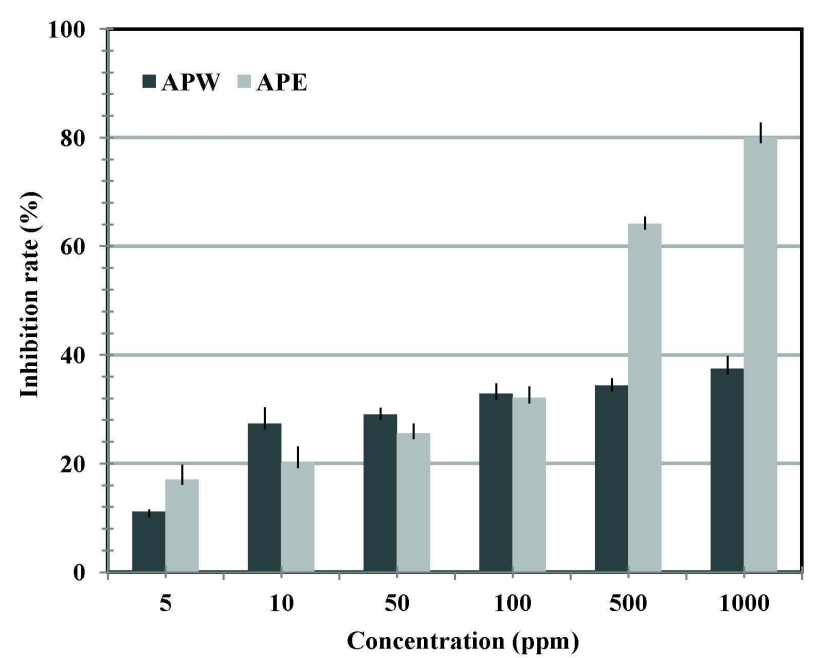

Fig. 7. Inhibition rate of Acanitum pseudolaeve var erectum Nakai. on collagenase. $\square$ APW: Aconitum pseudolaeve var erectum Nakai extracted with water. $\square$ APE: Aconitum pseuddaeve var erectum Nakai extracted with ethanol. Result are means \pm S.D. of triplicate data.

추출물의 collagenase 저해활성이 우수함을 확인할 수 있었다.

\section{Astringent 활성 측정}

Astringent는 피부나 점막의 국소에 작용하여 단백질을 응 고시켜 염증을 제거하고 피막을 만들어 보호하는 수렴제이다. 이러한 수렴작용의 원리는 피부 단백질이 고분자 flavonoids 와 결합하여 가교결합을 형성하여 피부가 수축하는 현상을 말하며 일반적으로 수렴제라고 알려진 것은 유기산 금속염이 나 무기산 금속염과 분자량이 적은 유기산 그리고 알코올(탄 소수가 적은 친수성 알코올)류 이다. 하지만 금속염은 금속이 갖고 있는 독성이나, 피부탈색 등의 여러 피부질환을 일으키 므로 피부에 사용하는 용도로는 부적합하며, 이로 인한 수렴 효과가 있는 천연물에 대한 관심이 높아지고 있다[13,20]. 이러 한 astringent 활성을 측정한 결과 Fig. 8 과 같이 나타내었다. 진범의 열수 추출물과 에탄올 추출물은 $5,000 \mathrm{ppm}$ 에서 각각 $51.8 \%, 13.8 \%$ 의 활성을 나타내어 에탄올 추출물에서 보다 열 수 추출물에서의 활성이 비교적 높은 것으로 확인하였다. 이 는 Kim 등[13]의 연구에서 판람근 열수 및 에탄올추출물 5,000 $\mathrm{ppm}$ 에서 각각 $9.3 \%, 21 \%$ 의 수렴효과를 보인 것과 비교해 진 범 추출물의 수렴효과를 확인할 수 있었다.

\section{MTT assay에 의한 세포 생존율 측정}

진범 추출물 자체가 세포독성으로 인한 cell population의 저하에서 기인하였는지를 확인하기 위하여 진범의 열수 및 에탄올 추출물의 농도별 세포 생존율을 측정해본 결과 Fig. 9 와 같이 나타내었다. 진범의 열수 추출물은 $1,000 \mathrm{ppm}$ 에서 $74.6 \%$ 의 생존율을 나타내었고, 에탄올 추출물은 같은 농도에 서 $78.1 \%$ 를 나타내어 비교적 낮은 세포 독성을 확인할 수 있었

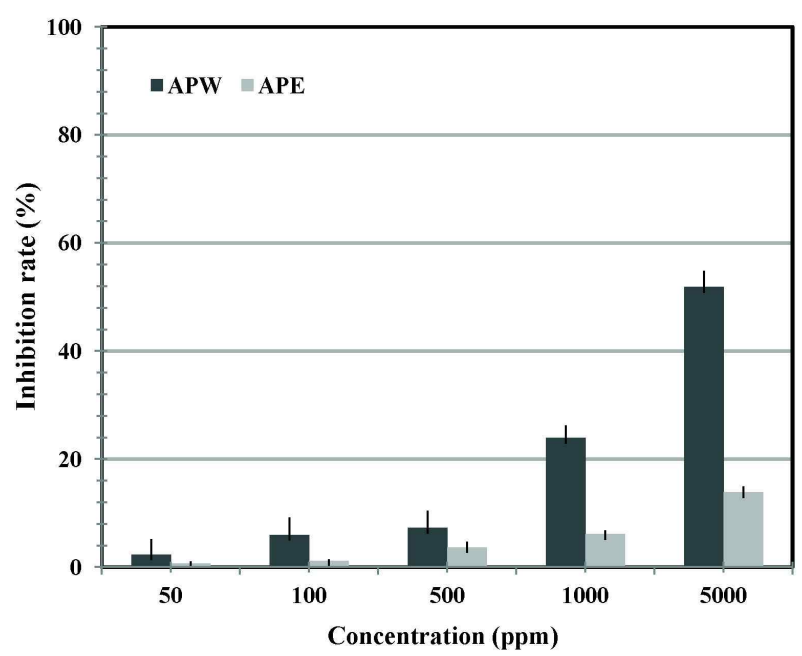

Fig. 8. Comparison of astringent activity of Aconitum pseudolaeve var erectum Nakai. $\square$ APW : Aconitum pseudolaeve var erectum Nakai extracted with water. $\square$ APE: Aconitum pseudolaeve var erectum Nakai extracted with ethanol. Result are means \pm S.D. of triplicate data.

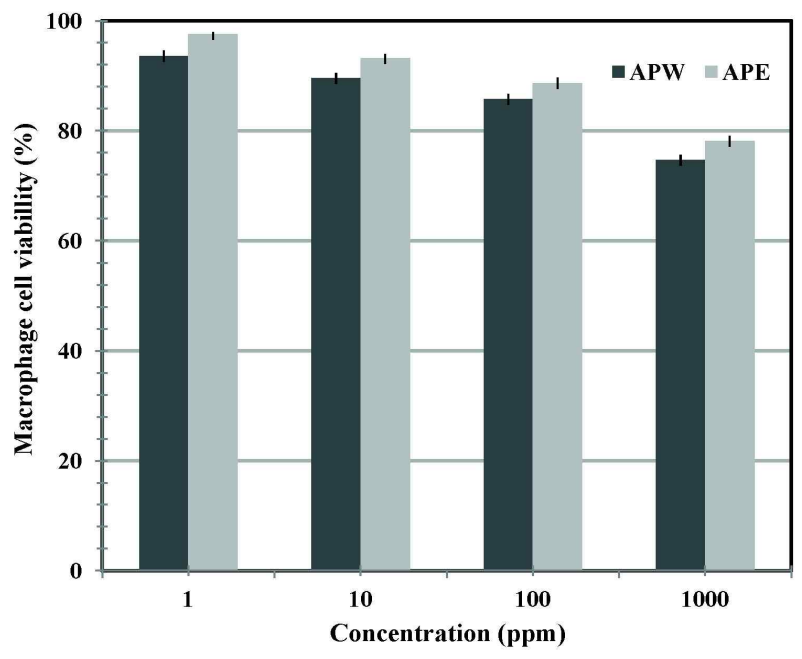

Fig. 9. Cell viability of Aconitum pseudolaeve var erectum Nakai. extracts on macrophage cell (Raw 264.7). $\square$ APW: Aconitum pseudolaeve var erectum Nakai extracted with water. $\square$ APE: Aconitum pseudolaeve var erectum Nakai extracted with ethanol. Result are means \pm S.D. of triplicate data.

으며, 이에 $\mathrm{NO}$ 의 저해활성을 $100 \mathrm{ppm}$ 이하에서 측정하였다.

\section{Nitric oxide 저해활성 측정}

체내 염증과정에서는 과량의 nitric oxide $(\mathrm{NO})$ 염증인자가 유도형 NO synthase에 의해 형성된다. 이 중 $\mathrm{NO}$ 는 체내 방어 기능, 신호전달기능, 신경독성, 혈관확장 등의 다양한 생리기 능을 가지고 있다[26]. 일반적으로 NO의 형성은 박테리아를 죽이거나 종양을 제거시키는 중요한 역할을 하지만 병리학적 


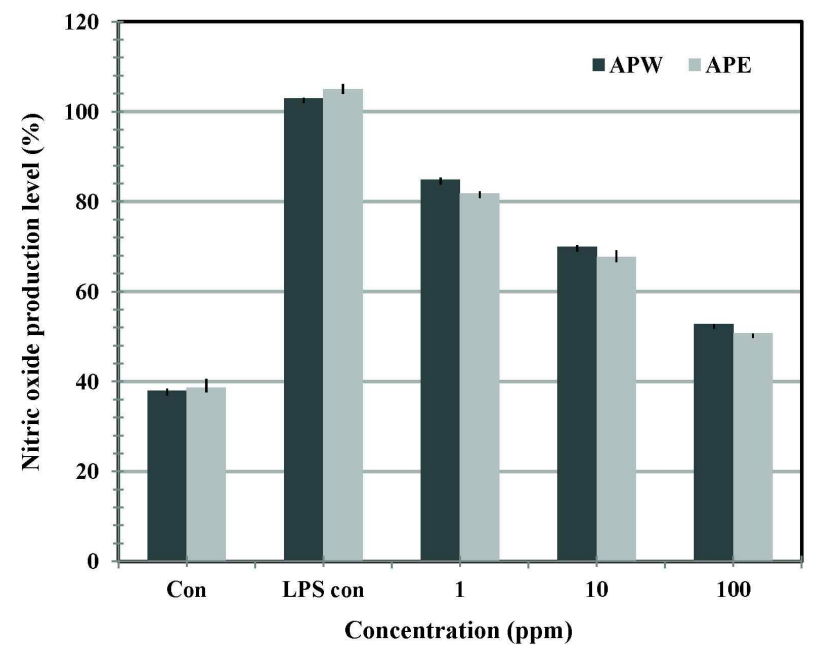

Fig. 10. Effects of Aconitum pseudolaeve var erectum Nakai. extracts on the production of nitric oxide in Raw 264.7 cells. $\square$ APW: Aconitum pseudolaeve var erectum Nakai extracted with water. $\square$ APE: Aconitum pseudolaeve var erectum Nakai extracted with ethanol. Result are means \pm S.D. of triplicate data.

인 원인에 의한 과도한 $\mathrm{NO}$ 의 형성은 염증을 유발시키게 되며, 조직의 손상, 유전자 변이 및 신경손상 등을 유발한다[25,26]. 진범의 열수 및 에탄올추출물을 이용하여 Raw 264.7cell의 $\mathrm{NO}$ 생성억제 정도를 측정한 결과 Fig. 10과 같이 나타내었다. LPS 처리군은 LPS 무처리군에 비하여 높은 NO발현량을 나타 내었으며, 진범의 열수 및 에탄올 추출물에서도 $\mathrm{NO}$ 발현을 감 소시키는 것을 확인할 수 있었다. 특히 진범 열수 및 에탄올 추출물 $100 \mathrm{ppm}$ 에서 $50 \%$ 에 가까운 저해율을 나타내었다. 이 는 Jeong 등[9]의 상황버섯, 발아현미상화버섯이 $100 \mathrm{ppm}$ 의 농도에서 $50 \%$ 에 가까운 $\mathrm{NO}$ 생성 저해능을 보인 결과와 비교 하여 유사한 효능을 나타내었다.

결론적으로 진범의 화장품약리학적 활성과 천연 향이 뇌파 에 미치는 영향을 볼 때 진범은 화장품 및 향료 개발의 천연소 재로 가능성이 있을 것으로 사료된다.

\section{감사의 글}

본 연구는 보건복지부 보건의료연구개발사업의 지원에 의 하여 이루어진 것임(과제번호: A103017).

\section{References}

1. Acuna, B. D., Eliassen, J. C., Donoghue, J. P. and Sanes, J. N. 2002. Frontal and parietal lobe activation during transitive inference in humans. Cereb. Cortex 12, 1312-1321.

2. Anderson, R. and Mohme-Lundholm, E. 1969. Studies on the relaxing actions mediated by stimulation of adrenergic alpha- and beta- receptors in taenia coli of the rabbit and guinea pig. Acta. Physiol. Scand 77, 372-384.

3. Artru, P. and Lledo, G. 2005. Traitement adjuvant du cancer du colon a l'asco : L' oxaliplatine accroit sa suprematie. Acta endoscopica, 35, 710.

4. Blois, M. S. 1958. Antioxidant determination by the use of a stable free radical. Nature 26, 1199-1120.

5. Carmichael, J., DeGraff, W. G., Gazdar, A. F., Minna, J. D. and Mitchell, J. B. 1987. Evaluation of a tetrazolium based semiautomated colorimetric assay: assessment of chemosensitivity testing. Cancer Res. 47, 936-942.

6. Choi, M. E., Jeon, B. K., Kim, D. S., Mun, Y. J. and Woo, W. H. 2009. A study on application for beauty food of mixture of Korean red ginseng and Fagopyrum esculentum: Anti-oxidative effect and collagenase inhibitory activity. Kor. J. Oriental Med Prescription 17, 153-162.

7. Hong, S. K., Jeong, D. M., Kim, K. Y. and Hwang, E. H. 2010. The composition of the root of lxeris dentata var. albiflora Nakai, and cell viability and DPPH radical scavenging activities of its extract. Kor. J. Nutr. 43, 105-113.

8. Huh, M., Lawson, A. E. and Kwon, Y. J. 1997. The role of prefrontal lobes in scientific reasoning. J. Kor. Assoc. Sci. Edu. $17,525-540$.

9. Jeong, Y. J., Choi, S. Y., An, C. S., Jeon, Y. H., Park, D. K. and Lim, B. O. 2009. Comparative effect on anti-inflammatory activity of the Phellinus linteus and Phellinus linteus grown in germinated brown rice extracts in murine macrophage Raw 264.7 cells. Kor. J. Med Crop. Sci. 17, 97-101.

10. Jung, H. J. 2009. The effects of augmentative and alternative communication on SMR-wave and $\beta$-wave of students with communication. MS Thesis, Daegu university, Daegu, Korea.

11. Kim, D. K., Kwak, J. H., Song, K. W., Kwon, H. C., Zee, O. P. and Lee, K. R. 1996. Phytochemical constituents from Aconitum pseudolaeve var erectum. Kor. J. Pharmacogn. 27, 75-79.

12. Kim, J. R. 2009. Scientific analysis of QEEG activation for teaching reading using digital text to elementary school students. MS Thesis, KyungSung University, Busan, Korea.

13. Kim, Y. H., Cho, W. A., Cheon, S. J., Jang, M. J., Sung, J. Y., Jung, S. H., Choi, H. J., Kim, D. I., Kim, J. O., Lee, C. E., An, B. J. and Lee, J. T. 2007. Study on anti-oxidant and cosmeceutical activities of Isatis tinctoria L. Kor. J. Herbol. 22, 85-91.

14. Kim, Y. J. and Chang, N. G. 2000. Development of a brain-cycle learning model based on the rhythmicity in brain functions and its test by brain wave's measure. Kor. J. Biol. Edu. 28, 396-407.

15. Klem, G. H., Luders, H. O., Jasper, H. H. and Elger, C. 1958. The ten-twenty electrode system of the international federation. Electroencephalogr. Clin. Neurophysiol. Suppl. 52, 3-6.

16. Klimesch, W. 1995. Memory processes described as brain oscillations in the EEG-alpha and theta bands. Psychology 11, 134-143. 
17. Kropotov, J. D. 2009. Quantitative EEG, event-related potentials and neurotherapy. pp. 59-76. Academic Press, San Diego, California.

18. Lee, H. S. and Chung, B. S. 1989. Studies on Korean Aconitum Species $(V)$. On the chemical constituents of aconitum pseudolaeve var erectum. Kor. J. Pharmaecogn. 20, 6-9.

19. Lee, I. H. 1997. Psychophysiology, pp.15-16. Hakjisa Press, Seoul, Korea.

20. Lee, J. T., Jeong, Y. S. and An, B. J. 2002. Physiological activity of Salicornia herbacea and its application for cosmetic materials. Kor. J. Herbol. 17, 51-60.

21. Lee, S. K., Kim, Y. W., Shin, D. Y., Lim, M. K., Lee, J. H., Song, J. M. and Kim, L. H. 2007. The changes of electroencephalography according to emotional stimulus in Sasangin. J. Sasang Constitution Med 19, 113-126.

22. Lee, T. W., Kim, S. N., Jee, U. K. and Hwang, S. J. 2004. Anti-wrinkle effect of pressure sensitive adhesive hydrogel patches containing Ulmi cortex extract. J. Kor. Pharm Sci. 34, 193-199.

23. Marklund, S. and Marklund, G. 1974. Involvement of the superoxide anion radical in the autoxidation of pyrogallol and a convenient assay for superoxide dismutase. Eur. J. Biochem 47, 469-474.
24. Menon, V., Rivera, S. M., White, C. D., Eliez, S., Glover, G. H. and Reiss, A. L. 2000. Functional optimization of arithmetic processing in perfect performers. Cognitive Brain Res 9, 343-345.

25. Moncada, S., Palmer, R. M. and Higgs, E. A. 1991. Nitric oxide: physiology, patho- physiology, and pharmacology. Pharmacol. Rev. 43, 109-142.

26. Nathan, C. 1992. Nitric oxide as a secretory product of mammalian cells. Faseb. J. 6, 3051-3064.

27. Park, C. W. 1998. Brain: Structure of learning and memory. pp. 1-76, Seoul National University Press, Seoul, Korea.

28. Park, S. J., Oh, S. B., Lee, E. J. and Seo, H. J. 2012. Psychophysiological evaluation for naturally flavored cream products. Kor. J. Sci. Emotion Sensibility 15, 9-16.

29. Seo, I. A. 2010. Studies on cosmeceutical of Phasedus radiates. MD. Thesis, Daegu Haany University, Gyeongsan, Korea.

30. Seong, K. E. 2008. The effect of mathematical activity on a learner's brain activity. MS. Thesis, Ajou University, Suwon, Korea.

31. Wûnsch, E. and Heindrich, H. G. 1963. Zur quantitativen bestimmung der collagenase. Hoppe-Seyler's. Physiol. Chem 333, 149-151

\section{초록 : 진범(Aconitum pseudolaeve var erectum Nakai)의 생리활성과 진범 향이 뇌파에 미치는 영향 \\ 이진영 ${ }^{1} \star \cdot$ 최연희 ${ }^{2} \cdot$ 이새미 $\left.\right|^{2} \cdot$ 이수연 $^{1} \cdot$ 전혜지 ${ }^{1}$ \\ (호서대학교 한방화장품과학과, ${ }^{2}$ (주제이에스향료 연구소 조향팀)}

본 연구는 진범의 in-vitro 생리활성과 진범 향이 신경생리학적으로 뇌파에 미치는 영향을 비교 분석하였다. 그 결과 진범 향 및 재조합 향 흡입 시 흡입 전에 비해 뇌파지표 absolute alpha power spectrum (AA)와 absolute theta power spectrum $(\mathrm{AT})$ 가 유의미하게 감소하였으며 $(p<0.05)$, 진범과 진범 재조합 향 흡입 시 출현한 파 형의 유발 부위가 각각 조금씩 다른 양상을 나타내기는 하였지만, 동일하게 alpha와 theta파가 나타났으며, 증가 율 역시 향 흡입 시 감소하는 동일 양상을 나타내어 뇌에 각성효과를 일으킨 것으로 판단된다. 진범의 생리활성 검증 결과 수렴효과를 제외한 $\mathrm{DPPH}$, collagenase, nitric oxide 저해활성 검증에서 진범 에탄올 추출물의 활성이 열수 추출물에 비해 우수하였으며, 특히 collagenase저해활성에서 진범 에탄올 추출물 $500 \mathrm{ppm}$ 에서 $80 \%$ 의 저 해활성을 나타내었으며, 또한 nitric oxide 저해활성에서 진범 열수 및 에탄올 추출물 $100 \mathrm{ppm}$ 에서 $50 \%$ 이상의 $\mathrm{NO}$ 저해활성을 나타내었다. 이러한 결과로부터 진범은 화장품 및 향료 개발의 천연소재로 사용이 가능할 것으 로 판단된다. 